\title{
Effect of thermal annealing in vacuum on the photovoltaic properties of electrodeposited $\mathrm{Cu}_{2} \mathrm{O}$-absorber solar cell
}

\author{
T. Dimopoulos ${ }^{1, a}$, A. Peić ${ }^{1, b}$, S. Abermann ${ }^{1}$, M. Postl ${ }^{2}$, E.J.W. List-Kratochvil ${ }^{2,3}$, and R. Resel ${ }^{3}$ \\ 1 AIT-Austrian Institute of Technology, Energy Department, Giefinggasse 2, 1221 Vienna, Austria \\ 2 NanoTecCenter Weiz Forschungsgesellschaft mbH, Franz-Pichler-Str. 32, 8160 Weiz, Austria \\ ${ }^{3}$ Graz University of Technology, Institute of Solid State Physics, Petergasse 16, 8010 Graz, Austria
}

Received: 24 October 2013 / Received in final form: 15 April 2014 / Accepted: 15 April 2014

Published online: 7 July 2014

(C) Dimopoulos et al., published by EDP Sciences, 2014

\begin{abstract}
Heterojunction solar cells were fabricated by electrochemical deposition of $p$-type, cuprous oxide $\left(\mathrm{Cu}_{2} \mathrm{O}\right)$ absorber on sputtered, $n$-type $\mathrm{ZnO}$ layer. X-ray diffraction measurements revealed that the asdeposited absorber consists mainly of $\mathrm{Cu}_{2} \mathrm{O}$, but appreciable amounts of metallic $\mathrm{Cu}$ and cupric oxide $(\mathrm{CuO})$ are also present. These undesired oxidation states are incorporated during the deposition process and have a detrimental effect on the photovoltaic properties of the cells. The open circuit voltage $\left(V_{\mathrm{OC}}\right)$, short circuit current density $\left(j_{\mathrm{SC}}\right)$, fill factor $(F F)$ and power conversion efficiency $(\eta)$ of the as-deposited cells are $0.37 \mathrm{~V}, 3.71 \mathrm{~mA} / \mathrm{cm}^{2}, 35.7 \%$ and $0.49 \%$, respectively, under AM1.5G illumination. We show that by thermal annealing in vacuum, at temperatures up to $300{ }^{\circ} \mathrm{C}$, compositional purity of the $\mathrm{Cu}_{2} \mathrm{O}$ absorber could be obtained. A general improvement of the heterojunction and bulk materials quality is observed, reflected upon the smallest influence of the shunt and series resistance on the transport properties of the cells in dark and under illumination. Independent of the annealing temperature, transport is dominated by the space-charge layer generation-recombination current. After annealing at $300{ }^{\circ} \mathrm{C}$ the solar cell parameters could be significantly improved to the values of: $V_{\mathrm{OC}}=0.505 \mathrm{~V}, j_{\mathrm{SC}}=4.67 \mathrm{~mA} / \mathrm{cm}^{2}, F F=47.1 \%$ and $\eta=1.12 \%$.
\end{abstract}

\section{Introduction}

Cuprous oxide $\left(\mathrm{Cu}_{2} \mathrm{O}\right)$ is one of the first known semiconducting materials. Although its photovoltaic (PV) property was very early recognized [1], the technological advancements towards a $\mathrm{Cu}_{2} \mathrm{O}$-based solar cell were only sporadic. Presently, $\mathrm{Cu}_{2} \mathrm{O}$ attracts increased attention, driven by the need for abundant and environmentalfriendly materials for PV and by newly introduced technological approaches for solar cell fabrication. In a recent study, $\mathrm{Cu}_{2} \mathrm{O}$ appears as one of the most intriguing among 23 inorganic absorbers for abundant and affordable electricity supply, based on the dual constraints of material supply and lowest cost per watt [2].

Indeed, $\mathrm{Cu}_{2} \mathrm{O}$ is abundant, non-toxic and can be prepared by non-vacuum techniques, such as thermal oxidation of $\mathrm{Cu}$ sheets and electrochemical deposition (ECD). It is a native $p$-type semiconductor, due to a high

\footnotetext{
${ }^{a}$ e-mail: theodoros.dimopoulos@ait.ac.at

b Present address: EV Group E. Thallner GmbH, DI Erich Thallner Str. 1, 4782 St. Florian am Inn, Austria.
}

concentration of negatively-charged copper vacancies [3]. Its direct bandgap of $\sim 2 \mathrm{eV}$ is quite large for an ideal match of the solar spectrum, but still allows for a theoretical maximum power conversion efficiency of $\sim 20 \%$ for a single junction under AM1.5 illumination [4]. This is combined with a high absorption coefficient for energies above the bandgap $\left(10^{3}\right.$ up to more than $\left.10^{5} \mathrm{~cm}^{-1}\right)$ [5], high majority carrier mobility (in the range of $100 \mathrm{~cm}^{2} / \mathrm{Vs}$ ) $[6,7]$ and large minority carrier diffusion length (up to several micrometers) $[8,9]$. Early investigations showed that $\mathrm{Cu}_{2} \mathrm{O}$ Schottky barrier-type solar cells lead to poor PV performance [8] and pointed out the need for heterojunction or homojunction architectures. Since the $n$-type doping of $\mathrm{Cu}_{2} \mathrm{O}$ is extremely difficult due to the mechanism of dopant self-compensation [10], research efforts focused inevitably on heterojunctions. Many $n$-type window layers have been tested for this purpose, such as $\operatorname{In}_{2} \mathrm{O}_{3}[11,12]$, $\mathrm{SnO}_{2}$ [11], $\mathrm{CdO}[11,13], \mathrm{Cu}_{x} \mathrm{~S}$ [14], $\mathrm{TiO}_{2}$ [15], $\mathrm{Ga}_{2} \mathrm{O}_{3}$ [16] and $\mathrm{ZnO}$, with the last two being the most promising.

Indeed, in 2006, an efficiency of more than $2 \%$ was achieved by sputter-depositing a thin $\mathrm{ZnO}$ layer on a bulk $\mathrm{Cu}_{2} \mathrm{O}$ substrate, produced by thermal oxidation of a $\mathrm{Cu}$ 
EPJ Photovoltaics

Table 1. List of the deposition parameters for each material, along with the corresponding sputter rates.

\begin{tabular}{|c|c|c|c|c|}
\hline Target & $\begin{array}{c}\text { Power } \\
\text { density } \\
\left(\mathrm{W} / \mathrm{cm}^{2}\right)\end{array}$ & Gas & Pressure $(\mathrm{Pa})$ & $\begin{array}{l}\text { Dep. rate } \\
(\mathrm{nm} / \mathrm{sec})\end{array}$ \\
\hline $\begin{array}{c}\mathrm{Al}: \mathrm{ZnO} \\
\text { (AZO) }\end{array}$ & $1.97(\mathrm{DC})$ & $\mathrm{Ar}$ & 0.1 & 0.78 \\
\hline $\mathrm{ZnO}$ & 0.49 (DC) & $\mathrm{Ar} / \mathrm{O}_{2}: 80 / 20$ & 1 & 0.08 \\
\hline $\mathrm{NiO}$ & $2.47(\mathrm{RF})$ & $\mathrm{Ar} / \mathrm{O}_{2}: 80 / 20$ & 0.5 & 0.04 \\
\hline $\mathrm{Au}$ & 0.43 (DC) & $\mathrm{Ar}$ & 0.2 & 0.32 \\
\hline
\end{tabular}

sheet at temperatures exceeding $1100{ }^{\circ} \mathrm{C}$ and process duration of several hours [7]. Through optimization of the thermal oxidation process and appropriate $\mathrm{ZnO}$ doping with $\mathrm{Mg}$, the efficiency increased to $4.3 \%$ for bulk $\mathrm{Cu}_{2} \mathrm{O}$ cells $[17,18]$. Recently, record efficiency of $5.38 \%$ was reported through the use of $\mathrm{Ga}_{2} \mathrm{O}_{3}$ n-layer [16]. However, the demand is to turn from bulk to thin film absorbers, which require significantly less material and lower fabrication cost. To this end, ECD of $\mathrm{Cu}_{2} \mathrm{O}$ has a large potential as it takes place close to room temperature (about $50-60{ }^{\circ} \mathrm{C}$ ) and from aqueous solution. In addition, ECD is easily up-scalable, high throughput and roll-to-roll compatible. However, the maximum achieved efficiency of solar cells with thin film, ECD-grown $\mathrm{Cu}_{2} \mathrm{O}$ in combination with $\mathrm{ZnO}$ remained for long limited at $1.28 \%$ [19]. Only very recently did the efficiency jump to $2.65 \%$ by employing a tin-doped $\mathrm{ZnO}$ layer, formed by atomic layer deposition and a substrate-type of solar cell [20].

The need remains to identify the factors that limit the efficiency of ECD $\mathrm{Cu}_{2} \mathrm{O}$ solar cells and introduce technological processes to address them. The heterojunction interface and the absorber bulk are of paramount importance for the charge carrier separation and collection. Enhanced recombination at the $\mathrm{ZnO} / \mathrm{Cu}_{2} \mathrm{O}$ interface arises due to structural defects and the large conduction band misalignment [21], leading to the degradation of the open circuit voltage and fill factor of the solar cell [22]. Further degradation is caused by current shunts related to a defect-rich heterojunction interface, as well as by the carrier recombination and large series resistance contributions associated with the absorber's bulk.

Thermal annealing can generally improve the quality of layers' interfaces and bulk. For potentiostaticallygrown $\mathrm{Cu}_{2} \mathrm{O}$ on $\mathrm{Cu}$ and $\mathrm{SnO}_{2}$, annealing in air was shown to promote crystallization, to lower the film's resistivity and to improve the conversion efficiency of photoelectrochemical cells [23]. On the other hand, the annealing of $\mathrm{Cu}_{2} \mathrm{O}$ films in air at elevated temperatures was reported to lead to the formation of $\mathrm{CuO}$ (cupric oxide) with poor $\mathrm{PV}$ properties [23].

In this paper we show that by thermal annealing $\mathrm{ZnO} / \mathrm{ECD}-\mathrm{Cu}_{2} \mathrm{O}$ solar cells in vacuum, the crystallinity and composition of the $\mathrm{Cu}_{2} \mathrm{O}$ absorber film are improved, eliminating the amounts of metallic $\mathrm{Cu}$ and $\mathrm{CuO}$ in the layer, which are incorporated during the electrochemical deposition. Furthermore, vacuum conditions prevent the oxidation of $\mathrm{Cu}_{2} \mathrm{O}$ to $\mathrm{CuO}$ that arises during annealing in air. Annealed solar cells present increased shunt resistance and lower series resistance, suggesting improvement of the heterojunction interface and absorber's bulk. The combination of these effects leads to the enhancement of the short circuit current, open circuit voltage and fill factor of the heterojunction solar cells.

\section{Experimental}

\subsection{Fabrication}

The solar cells were deposited on $1 \mathrm{~mm}$-thick glass slides. Apart from the $\mathrm{Cu}_{2} \mathrm{O}$ absorber, all other films were deposited by sputtering. During the sputter process, the targets and substrate holder were water-cooled at $25^{\circ} \mathrm{C}$. The target-substrate distance was $10 \mathrm{~cm}$ and the sputter chamber base pressure in the range of $7 \times 10^{-6}-1.2 \times$ $10^{-5} \mathrm{~Pa}$. All oxide films were sputtered from stoichiometric oxide targets. The deposition parameters of the films are shown in Table 1 . The film thicknesses and the corresponding sputter rates were extracted from step-height measurements using a surface profilometer.

Firstly, a $400 \mathrm{~nm}$-thick AZO layer was deposited on the glass slide, followed by the deposition of the intrinsic $\mathrm{ZnO}$ with a thickness of $40 \mathrm{~nm}$. ZnO covered the whole AZO surface except from a small window at the sample's edge, which is needed to establish a good contact to the sample during the ECD and later for the electrical measurements. AZO has a resistivity of $1.5 \times 10^{-3} \Omega \mathrm{cm}$, while the $i$ - $\mathrm{ZnO}$ is highly resistive $\left(>10^{5} \Omega \mathrm{cm}\right)$.

For the ECD of the $\mathrm{Cu}_{2} \mathrm{O}$ film, an aqueous solution with reagent-grade purified and deionized Milli- $Q$ water was prepared, containing $0.2 \mathrm{M} \mathrm{CuSO}_{4} \times 5 \mathrm{H}_{2} \mathrm{O}, 3 \mathrm{M}$ lactic acid and $125 \mathrm{mg}$ of $\mathrm{ZnO}$ powder, which was stirred for several hours until all grains were fully dissolved. A pH of 12.5 was reached by gradually adding $\mathrm{NaOH}$ to the solution. Lactic acid is used to stabilize $\mathrm{Cu}$ (II) ions at bath $\mathrm{pH}$ higher than 7, while the introduced $\mathrm{ZnO}$ powder served as sacrificial material in order to prevent the dissolution of the underlying $\mathrm{ZnO}$ layer during ECD and the formation of unwanted impurities, as proposed by Musselman et al. [24]. The reaction solution volume was $200 \mathrm{ml}$. The aqueous solution was heated under permanent mild stirring at the reaction temperature of $50{ }^{\circ} \mathrm{C}$ prior to the immersion of the AZO/ZnO-covered glass substrate (cathode), which was placed vertically in the reservoir. A wound platinum wire with a diameter of $0.5 \mathrm{~mm}$ was used as the counter electrode. A negative DC potential of $-0.6 \mathrm{~V}$ relative to an $\mathrm{Ag} / \mathrm{AgCl}$ reference electrode was applied 

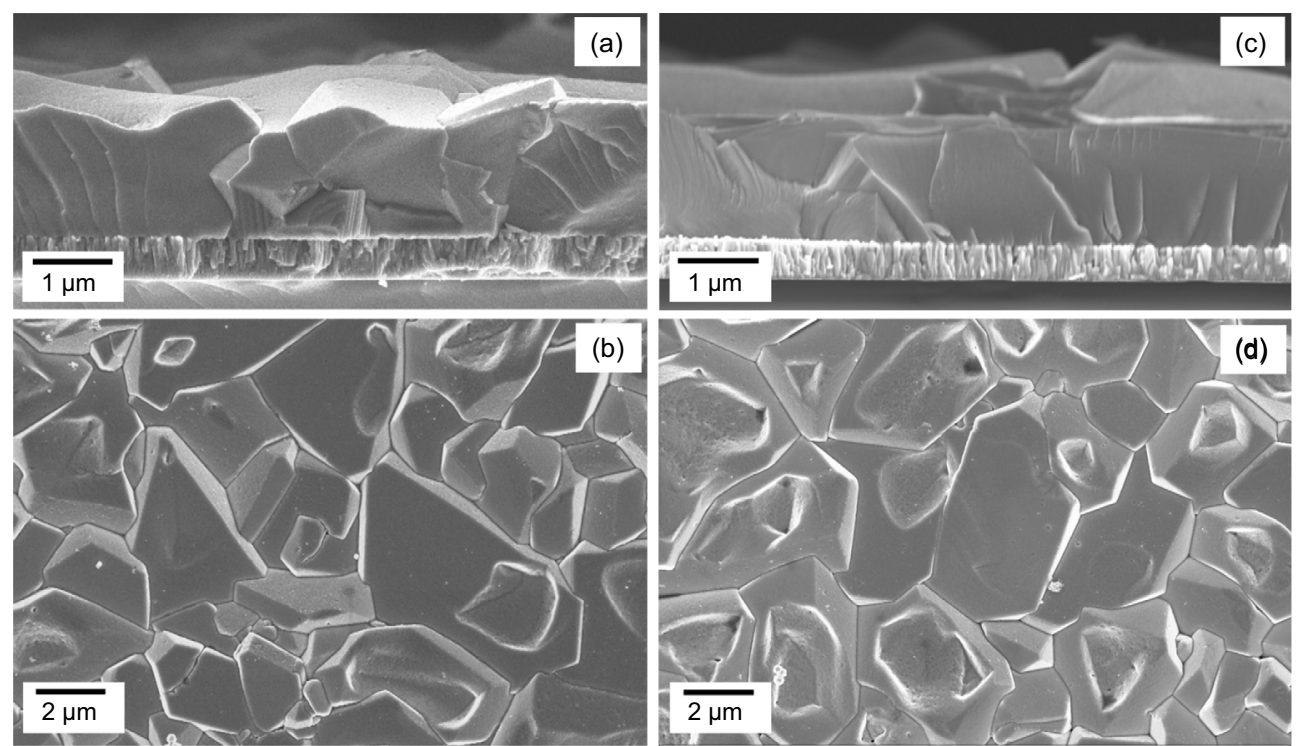

Fig. 1. Cross section and top view SEM images of the as-deposited heterojunction (a, b) and after annealing at $300{ }^{\circ} \mathrm{C}(\mathrm{c}, \mathrm{d})$.

for 70 min, using an AUTOLAB potentiostat/galvanostat. After the deposition the sample was removed from the solution and thoroughly rinsed in flowing deionized water to eliminate residual salts and unreacted products from the surface. Then the sample was transferred to the sputtering chamber for the deposition of $20 \mathrm{~nm}$ of $\mathrm{NiO}$, followed by $\mathrm{Au}$ deposition through a contact mask, to define solar cell areas from 1 to $9 \mathrm{~mm}^{2}$.

\subsection{As-deposited cell}

Figures 1a and 1b show scanning electron microscopy (SEM) images of the cleaved edge and of the surface of the as-deposited heterojunction, respectively (without the top $\mathrm{Au}$ contact). The sputtered $\mathrm{AZO}$ and $\mathrm{ZnO}$ layers have a characteristic columnar structure, while the $\mathrm{Cu}_{2} \mathrm{O}$ layer, of approximately $1.7 \mu \mathrm{m}$ thickness, is compact, rough and features large, flat-top grains, with sizes up to several micrometers. Large grain-size is important in order to keep the charge carrier scattering low and thus improve the absorber's conductivity and the minority carrier transport length by diffusion or drift. Two groups estimated the latter to be approximately $160 \mathrm{~nm}$ for electrodeposited $\mathrm{Cu}_{2} \mathrm{O}$ solar cells, much lower than for thermally oxidized $\mathrm{Cu}_{2} \mathrm{O}[25,26]$. It is admitted, though, that this value is sensitive to the structural properties of the absorber (crystallinity, grain size, defect density) and of the heterojunction quality.

The specular X-ray diffraction (XRD) pattern of the as-deposited multilayer in Figure 2 shows the typical hexagonal $\mathrm{ZnO}(002)$ plane reflection at $2 \theta=34.25^{\circ}$, with a secondary peak stemming from the (103) planes at $62.6^{\circ}$. In the case of $\mathrm{Cu}_{2} \mathrm{O}$, its structure is cubic with the dominant reflection coming from the (111) family of planes at $36.5^{\circ}$. The same preferred $\mathrm{Cu}_{2} \mathrm{O}$ texture was reported by potentiostatic [27-29] or galvanostatic [19, 30] deposition, for solutions with high $\mathrm{pH}$. Indeed, the increase of hydroxyl ion concentration for high bath $\mathrm{pH}$,

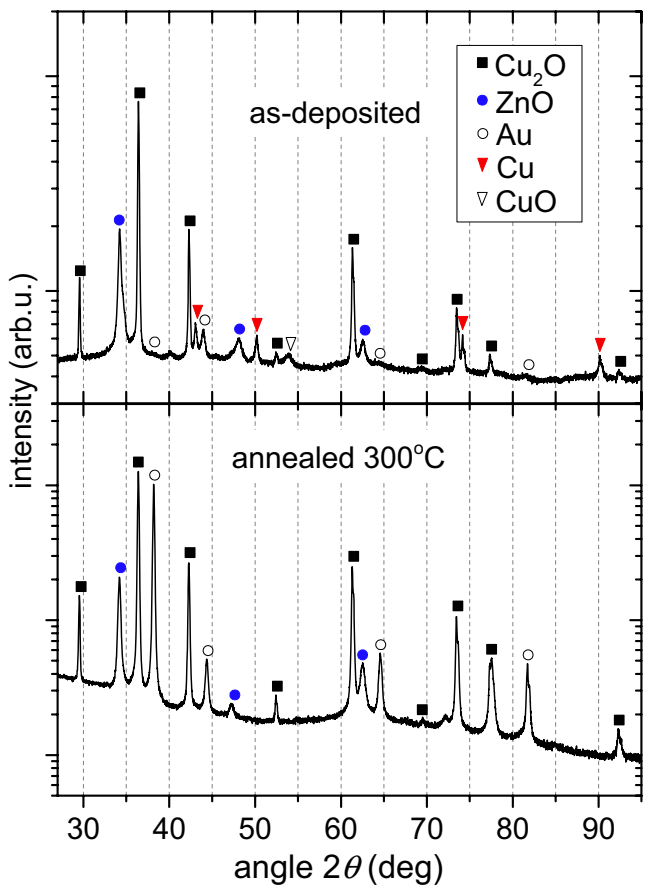

Fig. 2. Specular XRD measurements of the as-deposited and annealed cell at $300{ }^{\circ} \mathrm{C}$.

leads to increased oxygen supply in the film. This favors the growth of planes with high oxygen ion density, such as the (111) family of planes [31]. The XRD pattern also contains $\mathrm{Cu}_{2} \mathrm{O}$ peaks of smaller intensities at $2 \theta=42.3$, $61.4,29.6,73.5,77.6,52.4$ and $92.4^{\circ}$ (in descending intensity order), corresponding to the (200), (220), (110), (311), (222), (211) and (400) planes, respectively.

Most importantly, we also observe reflections from metallic $\mathrm{Cu}$ at $2 \theta=43.2,50.2,74.2$ and $90.1^{\circ}$, which correspond to the fcc (111), (200), (220) and (311) planes, respectively. Finally the peak at $2 \theta=53.9^{\circ}$ is ascribed to the monoclinic $\mathrm{CuO}$ (020) plane reflection. It is therefore 


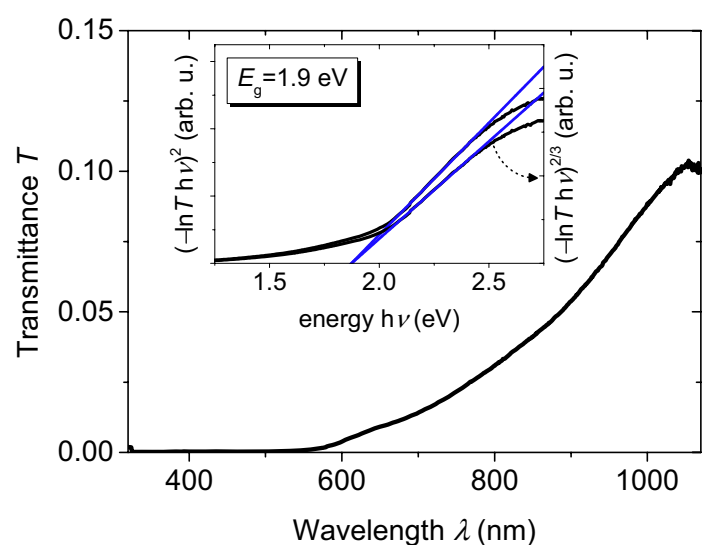

Fig. 3. Transmittance spectrum (excluding the glass substrate) and Tauc plot (inset) from where the direct bandgap of $\mathrm{Cu}_{2} \mathrm{O}$ is extracted (as-deposited sample).

shown that the as-deposited absorber may predominantly consist of $\mathrm{Cu}_{2} \mathrm{O}$, but appreciable amounts of metallic $\mathrm{Cu}$ and $\mathrm{CuO}$ are present. Indeed, the oxidation state of the deposit is very sensitive on the applied ECD potential. For a fixed bath $\mathrm{pH}$, a more negative potential favors the deposition of $\mathrm{Cu}$, a moderate potential the deposition of $\mathrm{Cu}_{2} \mathrm{O}$ and the least negative the formation of $\mathrm{CuO}$ [32]. The limits between the different potential windows are not sharply defined, leading to the possibility that unwanted oxidation states are present in the film. In line with our findings, Septina et al. [29] reported the incorporation of $\mathrm{Cu}^{2+}$ and $\mathrm{Cu}^{0}$ impurities during potentiostatic ECD for a wide range of potential values. Also, it is pointed out that traces of these impurities may well be present, even if the corresponding phases cannot be resolved in the X-ray diffractogram [19]. The presence of metallic $\mathrm{Cu}$ in the absorber was shown to degrade the PV characteristics [19], while $\mathrm{CuO}$ also leads to reduced $\mathrm{PV}$ performance compared to $\mathrm{Cu}_{2} \mathrm{O}[28,33]$.

Figure 3 shows the optical transmittance, $T$, spectrum of the $\mathrm{AZO} / n-\mathrm{ZnO} / p-\mathrm{Cu}_{2} \mathrm{O}$ heterojunction, excluding the glass substrate, measured with a spectrophotometer. From this, the Tauc plot is constructed, i.e. the quantity $(-\ln T h \nu)^{m}$ versus $h \nu$, where $h v$ is the photon energy and $m$ an exponent, the value of which depends on the type of optical transition: $m=2$ for direct allowed transition and $m=2 / 3$ for direct forbidden. The inset of Figure 4 shows the curves for both exponent values, leading to equally good linear dependence at the absorption edge window. The linear extrapolation to the $h \nu$-axis yields in both cases a bandgap of $1.9 \mathrm{eV}$, in accordance with the anticipated value for $\mathrm{Cu}_{2} \mathrm{O}$.

Following the electrical characterization of the asdeposited solar cells, the sample was annealed in vacuum (base pressure in the $10^{-4} \mathrm{~Pa}$ regime) at temperatures of $200,250,300$ and $350{ }^{\circ} \mathrm{C}$ for $1 \mathrm{~h}$. The ramp-up time to the targeted temperature was 5-10 min, while the ramp-down time to room temperature was $4-6 \mathrm{~h}$. The cells were electrically characterized after each annealing step in dark and under AM1.5G illumination, before proceeding to the next temperature. The presented measurements

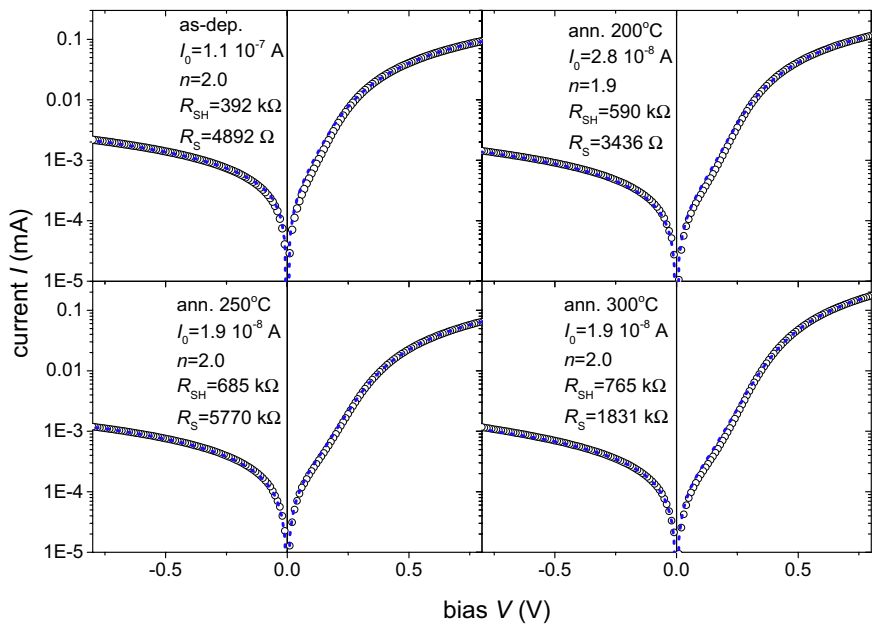

Fig. 4. Measured dark $I-V$ curves (open circles) for a solar cell with $6.5 \mathrm{~mm}^{2}$ area at the as-deposited state and after annealing at the marked temperatures. Dashed lines represent fits to equation (1), from where the saturation current, diode ideality factor, shunt and series resistance values are extracted.

concern a cell area of $6.5 \mathrm{~mm}^{2}$ (as defined by the size of the Au electrode). The current density was, nevertheless, practically independent of the cell area, showing that the current flow is homogeneous throughout the surface of the cell and that the influence of the cell's edges can be neglected. Also, the photovoltaic properties did not depend on whether a shadow mask was used for illumination or not, showing that the collection of current from outside the cell area is negligible. This is a consequence of the very resistive absorber, restricting lateral carrier transport.

\subsection{Annealed cell}

Figures 1c and 1d show cross section and surface SEM images of the sample after annealing at $300{ }^{\circ} \mathrm{C}$. No significant changes can be observed as opposed to the asdeposited sample (Figs. 1a and 1b). On the other hand, the XRD pattern of the annealed sample in Figure 2 is free of metallic $\mathrm{Cu}$ and $\mathrm{CuO}$ reflections, i.e. the absorber has acquired the pure $\mathrm{Cu}_{2} \mathrm{O}$ phase. In parallel, the intensities of the secondary $\mathrm{Cu}_{2} \mathrm{O}$ peaks relative to the principal (111) peak are notably higher. This is especially the case for the (211), (311), (222) and (400) plane reflections. We assume that this gain in intensity arises from the transformation of the $\mathrm{Cu}$ and $\mathrm{CuO}$ phases to $\mathrm{Cu}_{2} \mathrm{O}$.

The effects of vacuum annealing on the cells' electrical properties were investigated through dark and illuminated current-voltage $(I-V)$ measurements. After each annealing step the sample was kept in ambient conditions for 2 days before being measured. This period was necessary in order to obtain stable electrical properties from the solar cells. The dark $I-V$ s obtained for a $6.5 \mathrm{~mm}^{2}$ area cell as a function of the annealing temperature, are presented in Figure 4 in $\log I$ vs. $V$ plots. They are fitted to the onediode model expression:

$$
I=I_{0}\left[\exp \left(q\left(V-I R_{\mathrm{S}}\right) / n k T\right)-1\right]+\left(V-I R_{\mathrm{S}}\right) / R_{\mathrm{SH}}
$$


T. Dimopoulos et al.: Effect of annealing in vacuum on the PV properties of electrodeposited $\mathrm{Cu}_{2} \mathrm{O}$ solar cell

Table 2. Extracted device parameters from the $I-V$ measurements of the solar cells in dark and under AM1.5G illumination.

\begin{tabular}{lcccc}
\hline & As-dep. & $200{ }^{\circ} \mathrm{C}$ & $250{ }^{\circ} \mathrm{C}$ & $300{ }^{\circ} \mathrm{C}$ \\
\hline$n$ & 2.0 & 1.9 & 2.0 & 2.0 \\
$R_{\mathrm{SH}}(\mathrm{k} \Omega)-$ dark & 392 & 590 & 685 & 765 \\
$R_{\mathrm{S}}(\Omega)-$ dark & 4892 & 3436 & 5770 & 1831 \\
$I_{0}\left(10^{-8} \mathrm{~A}\right)$ & 11.0 & 2.8 & 1.9 & 1.9 \\
& & & & \\
$R_{\mathrm{SH}}(\Omega)-$ illum. & 4425 & 5867 & 6920 & 14689 \\
$R_{\mathrm{S}}(\Omega)-$ illum. & 889 & 1000 & 861 & 599 \\
$R_{\mathrm{CH}}(\Omega)$ & 1386 & 1282 & 1432 & 1494 \\
$R_{\mathrm{SH}} / R_{\mathrm{CH}}$ & 3.2 & 4.6 & 4.8 & 9.8 \\
$j_{\mathrm{SC}}\left(\mathrm{mA} / \mathrm{cm}^{2}\right)$ & 3.71 & 3.91 & 4.61 & 4.67 \\
$V_{\mathrm{OC}}(\mathrm{V})$ & 0.37 & 0.44 & 0.47 & 0.51 \\
$F F(\%)$ & 35.7 & 35.9 & 37.4 & 47.1 \\
$\eta(\%)$ & 0.49 & 0.62 & 0.81 & 1.12 \\
\hline
\end{tabular}

where $n$ the diode's ideality factor, $q$ the elementary charge, $k$ the Boltzmann's constant, $T$ the temperature in Kelvin, $I_{0}$ the diode's saturation current, $R_{\mathrm{SH}}$ the shunt resistance and $R_{\mathrm{S}}$ the series resistance. The fit yields in all cases ideality factors close to $n=2.0$ (Tab. 2), which suggests that transport is dominated by the space-charge layer generation-recombination current as described by the Sah-Noyce-Shockley model [34], with the generationrecombination level located at mid-gap. The parasitic shunt resistance has an important contribution on the transport characteristics at reverse and low forward bias $(<0.2 \mathrm{~V})$. It stems from defect-rich junction regions with nearly ohmic behavior, resulting in a practically linear increase of the current with the bias. The value of $R_{\mathrm{SH}}$ rises constantly with increasing annealing temperature (Tab. 2). Since low shunt resistance is related to poor heterojunction quality, we conclude that thermal annealing has, indeed, improved the $\mathrm{ZnO} / \mathrm{Cu}_{2} \mathrm{O}$ interface. The improvement of the electronic quality of the materials forming the junction is also reflected upon the continuous decrease of the saturation current $I_{0}$ with the annealing temperature (Tab. 2), which can be related to the reduction of charge carrier recombination. Finally, the $R_{\mathrm{S}}$ values, related to the resistance of the semiconductor films and contacts and manifesting itself at large forward bias, also appear in Table 2 . Although $R_{\mathrm{S}}$ varies for intermediate annealing temperatures, there is a clear decrease of its value after annealing at $300{ }^{\circ} \mathrm{C}$, as compared to the asdeposited case. This $R_{\mathrm{S}}$ reduction can be partly attributed to the reduction of the $\mathrm{Cu}_{2} \mathrm{O}$ resistivity. Indeed, the resistivity of $\mathrm{Cu}_{2} \mathrm{O}$ after annealing at $300{ }^{\circ} \mathrm{C}$ is found to moderately decrease to $7.2 \times 10^{4} \Omega \mathrm{cm}$ from the $11.6 \times 10^{4} \Omega \mathrm{cm}$ level of the as-deposited state.

The parasitic resistance values were also extracted from the illuminated $I-V$ curves in Figure 5 . The $R_{\mathrm{SH}}$ is obtained from the inverse of the curve's slope at $V=$ 0 (short circuit condition). We observe again a continuous increase of $R_{\mathrm{SH}}$ with the annealing temperature,

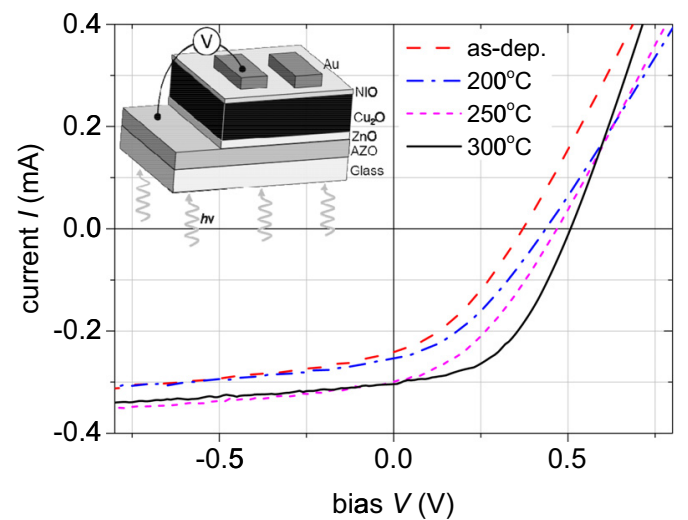

Fig. 5. $I-V$ curves measured under simulated solar spectrum (AM1.5G) for a cell of $6.5 \mathrm{~mm}^{2}$ area after being annealed at different temperatures. Inset shows schematic of the solar cell structure.

which becomes especially large after annealing at $300{ }^{\circ} \mathrm{C}$ (Tab. 2). The fact that $R_{\mathrm{SH}}$ is much lower under illumination than in dark suggests that the shunting paths are photoactive. The cell's series resistance, as extracted from the $I-V$ slope at $I=0$ (open circuit condition), significantly reduces at $300{ }^{\circ} \mathrm{C}$. The difference between dark and illuminated values is not as strong here as with the case of $R_{\mathrm{SH}}$.

Also important is the fact that the characteristic cell resistance, $R_{\mathrm{CH}}$, at the point of maximum power, is not significantly modified by the annealing, resulting to a steady improvement of the $R_{\mathrm{SH} /} R_{\mathrm{CH}}$ ratio (Tab. 2). As a consequence of the considerable increase of $R_{\mathrm{SH}}$ and the decrease of $R_{\mathrm{S}}$, an improvement of the fill factor from 37.4 to $47.1 \%$ is achieved after annealing at $300{ }^{\circ} \mathrm{C}$ (Tab. 2). In parallel, the open circuit voltage, $V_{\mathrm{OC}}$, of the cell reaches $505 \mathrm{mV}$ after annealing at $300{ }^{\circ} \mathrm{C}$, steadily increasing from the $370 \mathrm{mV}$ value of the as-deposited state. Likewise, the short circuit current density, $j_{\mathrm{SC}}$, increases with the temperature from 3.71 to $4.67 \mathrm{~mA} / \mathrm{cm}^{2}$. As a result, the power conversion efficiency, $\eta$, improves from $0.49 \%$ for the asdeposited case to $1.12 \%$ after annealing at $300{ }^{\circ} \mathrm{C}$ (Tab. 2). We note here that further annealing at $350{ }^{\circ} \mathrm{C}$ for $1 \mathrm{~h}$ resulted to linear $I-V$ characteristics for the majority of the cells, which strongly suggests the formation of short-cuts at the heterojunction.

In conclusion, we showed that thermal annealing in vacuum can considerably improve the photovoltaic performance of solar cells with electrochemically-deposited $\mathrm{Cu}_{2} \mathrm{O}$. The composition of the annealed absorber is purely $\mathrm{Cu}_{2} \mathrm{O}$, with no traces of $\mathrm{CuO}$ and $\mathrm{Cu}$, as it is the case for the as-deposited films. The electrical characterization of the solar cells in dark and under AM1.5G illumination showed that the influence of the shunt and series resistance is decreased with annealing and all PV parameters are improved, obtaining a maximum power conversion efficiency of $1.12 \%$.

The authors would like to acknowledge financial support from the Austrian Klima \& Energiefonds projects "SAN-CELL" and "CopperHEAD". 


\section{References}

1. B. Lange, Photoelements (Reinhold Publ. Corp., New York, 1938)

2. C. Wadia, A.P. Alivisatos, D.M. Kammen, Environ. Sci. Technol. 43, 2072 (2009)

3. W. Brattain, Rev. Mod. Phys. 23, 203 (1951)

4. W. Shockley, H.J. Queisser, J. Appl. Phys. 32, 510 (1961)

5. C. Malerba, F. Biccari, C. Leonor Azanza Ricardo, M. D'Incau, P. Scardi, A. Mittiga, Sol. Energy Mater. Sol. Cells 95, 2848 (2011)

6. A. Musa, T. Akomolafe, M. Carter, Sol. Energy Mater. Sol. Cells 51, 305 (1998)

7. A. Mittiga, E. Salza, F. Sarto, M. Tucci, R. Vasanthi, Appl. Phys. Lett. 88, 163502 (2006)

8. L.C. Olsen, F.W. Addis, W. Miller, Sol. Cells 7, 247 (1982)

9. F. Biccari, C. Malerba, A. Mittiga, Sol. Energy Mater. Sol. Cells 94, 1947 (2010)

10. Y. Tsur, I. Riess, Phys. Rev. B 60, 8138 (1999)

11. L. Papadimitriou, N.A. Economou, D. Trivich, Sol. Cells 3, $73(1981)$

12. C.J. Dong, W.X. Yu, M. Xu, J.J. Cao, C. Chen, W.W. Yu, Y.D. Wang, J. Appl. Phys. 110, 073712 (2011)

13. Y. Hameş, S. Eren San, Sol. Energy 77, 291 (2004)

14. R. Wijesundara, L.D.R. Perera, K. Jayasuriya, W. Siripala, K.T. De Silva, A. Samantilleke, I. Dharmadasa, Sol. Energy Mater. Sol. Cells 61, 277 (2000)

15. S. Hussain, C. Cao, Z. Usman, Z. Chen, G. Nabi, W.S. Khan, Z. Ali, F.K. Butt, T. Mahmood, Thin Solid Films 522, 430 (2012)

16. T. Minami, Y. Nishi, T. Miyata, Appl. Phys. Express 6, 044101 (2013)

17. T. Minami, Y. Nishi, T. Miyata, J. Nomoto, Appl. Phys. Express 4, 062301 (2011)

18. T. Minami, N. Yuki, T. Miyata, A. Shinya, in Pacific Rim Meeting on Electrochemical and Solid-State Science (PRiME), 222nd Meeting of ECS, Honolulu, 2012
19. M. Izaki, T. Shinagawa, K.-T. Mizuno, Y. Ida, M. Inaba, A. Tasaka, J. Phys. D 40, 3326 (2007)

20. Y.S. Lee, J. Heo, S.C. Siah, J.P. Mailoa, R.E. Brandt, S.B. Kim, R.G. Gordon, T. Buonassisi, Energy Environ. Sci. 6 2112 (2013)

21. B. Kramm, A. Laufer, D. Reppin, A. Kronenberger, P. Hering, A. Polity, B.K. Meyer, Appl. Phys. Lett. 100, 094102 (2012)

22. T. Minemoto, T. Matsui, H. Takakura, Y. Hamakawa, T. Negami, Y. Hashimoto, T. Uenoyama, M. Kitagawa, Sol. Energy Mater. Sol. Cells 67, 83 (2001)

23. T. Mahalingam, J.S.P. Chitra, J.P. Chu, S. Velumani, P.J. Sebastian, Sol. Energy Mater. Sol. Cells 88, 209 (2005)

24. K.P. Musselman, A. Marin, A. Wisnet, C. Scheu, J.L. MacManus-Driscoll, L. Schmidt-Mende, Adv. Funct. Mater. 21, 573 (2011)

25. Y. Liu, H.K. Turley, J.R. Tumbleston, E.T. Samulski, R. Lopez, Appl. Phys. Lett. 98, 162105 (2011)

26. K.P. Musselman, Y. Ievskaya, J.L. MacManus-Driscoll, Appl. Phys. Lett. 101, 253503 (2012)

27. T. Mahalingam, J.S.P. Chitra, J.P. Chu, S. Velumani, P.J. Sebastian, Sol. Energy Mater. Sol. Cells 88, 209 (2005)

28. S. Hussain, C. Cao, G. Nabi, W.S. Khan, Z. Usman, T. Mahmood, Electrochimica Acta 56, 8342 (2011)

29. W. Septina, S. Ikeda, M.A. Khan, T. Hirai, T. Harada, M. Matsumura, L.M. Peter, Electrochimica Acta 56, 4882 (2011)

30. S.S. Jeong, A. Mittiga, E. Salza, A. Masci, S. Passerini, Electrochimica Acta 53, 2226 (2008)

31. L. Wang, Ph.D. thesis, The University of Texas at Arlington, pp. 55-58, 2006

32. L. Chen, S. Shet, H. Tang, H. Wang, T. Deutsch, Y. Yan, J. Turner, M. Al-Jassim, J. Mater. Chem. 20, 6962 (2010)

33. T. Dimopoulos, A. Peić, P. Müllner, M. Neuschitzer, R. Resel, S. Abermann, M. Postl, E.J.W. List, S. Yakunin, W. Heiss, H. Brückl, J. Renew. Sustain. Energy 5, 011205 (2013)

34. C. Sah, R. Noyce, W. Shockley, Proc. IRE 45, 1228 (1957) 